\title{
The use of oikovouí $\alpha$ in a missional reading of the Gospel of Luke-Acts
}

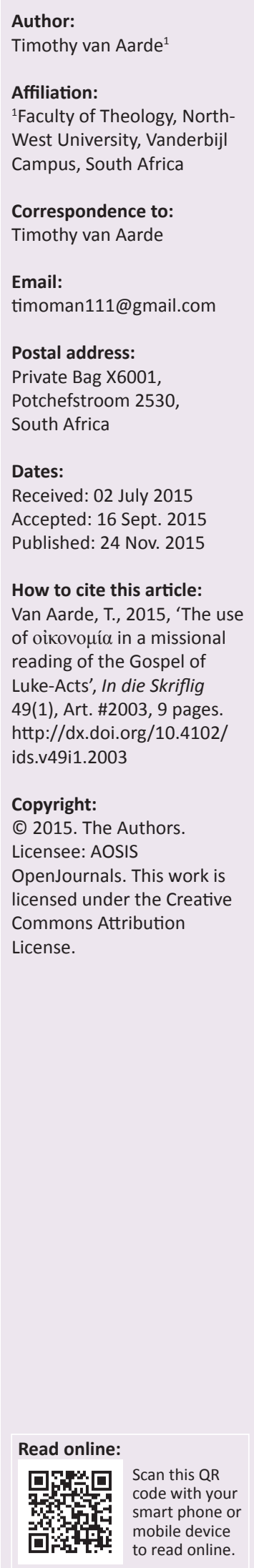

The term oikovopí $\alpha$ is important term the Gospel of Luke. The word oikovopía, in particular its meaning in Luke, is a perpetration and prerequisite for a missional reading of Luke-Acts. The dual motifs of creation and redemption are interdependently related from Genesis to Revelations. In the Gospel of Luke these motifs are unified in the sphere of the household as the most basic social structure through the oikovous management of the oikos, the household.

Die gebruik en betekenis van оiкоvонí $\alpha$ as 'n handeling en voorvereiste vir 'n missionale lees van die Evangelie van Lukas-Handelinge. Oikovo $\mu$ í $\alpha$ is ' $n$ belangrike term in die Evangelie van Lukas. Die woord oikovoría en veral die betekenis daarvan in Lukas is ' $n$ handeling en voorvereiste vir 'n missionale lees van Lukas-Handelinge. Die twee motiewe van skepping en verlossing is interafhanklik aan mekaar verbind vanaf Genesis tot Openbaring. In die Evangelie van Lukas word hierdie motiewe saamgebind in die sfeer van die huishouding as

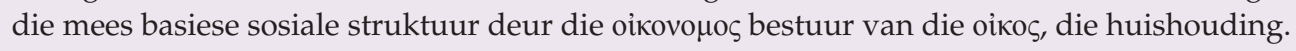

\section{Introduction}

Missions are an integral part of the redemptive plan of God in Scripture. God's plan begins in Genesis with the command to multiply and be fruitful (Gn 1:28), the 'Cultural' or 'Creation Mandate', and responsibility for the care of creation has been given to all mankind on the basis of the creation motif (Gn 2:15). The proto-Gospel or proto-evanglium (Gn 3:15) 'represents the absolute beginning of the history of revelation as it relates to the divine redemptive initiative' (Berthoud 2015:70). The redemption motif has been given to the restored and renewed people of God to whom the oikovoría of the new creation has been committed. The task of oikovoría in Luke is based on the dual motifs of creation and redemption. In the working-out of God's plan in Luke and Acts the concept of oikovouía, has the meaning of the resources' stewardship in the book of Luke. In the Pauline epistles the term oikovouía is used by Paul for the missions' activity of God, the missio Dei (Eph 1:10; cf. Van Aarde 2015:45-62), his own mission activity and the proclamation of the gospel (Eph 3:2,9). The term oikovouía is used in a different context by Luke than Paul in terms of the sphere of application of the term, which in Luke focuses on the temporary nature of the task of oikovo $\mu$ í $\alpha$ as a delegated responsibility and is applied by Paul to his own and the proclamation of others (Van Aarde 2015:48; cf. 1 Cor 4:1; 1 Pt 4:10; Tt 1:7; cf. Foster 1995:15).

The broad theological use of the term will be established and an exegetical study of the use of oikovoría in Luke-Acts will be made.

\section{The priestly task of stewardship from creation to re-creation}

The task of stewardship was given in Genesis 1:28 and the specific nature of the task is communicated as a responsibility given by God to mankind in Genesis 2:15. The task given to mankind by the Trinity has been minimalised to 'be fruitful and increase in number; fill the earth' (Gn 1:28). "The imperatives "Be fruitful", "increase", and "fill" are not to be understood as commands in this verse since the introductory statement identifies them as "blessings"' (Gaebelein 1990:38). In Genesis 1:28 וּמִִּאו can mean 'fill' or allude to mankind's task to be a blessing to creation - a priestly relation to God's creation. Mankind is blessed with the implication that mankind will be a blessing to creation. The meaning of rִדָדָהָ recounts the purpose that God 'put' man in the garden, which was more than simply 'to work it and take care of it'. (Gn 2:15, NIV). A more suitable translation of עָרָדָה in Genesis 2:15 is 'to serve and to guard' (Cassuto 1961:121), which indicates man's priestly role more concretely than 'work' and 'care'. Man is to consider his action as a service. "The verb עָבָב (Gn 2:15) means "to serve" and even to serve ritually in the temple and 
by extension to worship God' (Berthoud 2015:64). Berthoud (2015:64) eclipses what is essential about 'priestly service' when he identifies the fulfilment of a service exclusively with man exercising dominion and rules over creation in the presence of God (cf. Gn 1:28). ${ }^{1}$ One of the functions of the priests in Israel was to be stewards of the knowledge of God (cf. Hs 4:1-6; Ml 2:7; 2 Chr 15:3). Cassuto (1961) follows the rabbinic teaching (Bereshith Rabba, xvi 5):

which explains the term to refer to the sacrificial service, corresponds to an ancient tradition of the Orient, often mentioned in Mesopotamian inscriptions, according to which man was created for the express purpose of serving God. (p. 122)

The Torah attributed to man not only the duty of serving, but also that of guarding (cf. Cassuto 1961:123). A more suitable

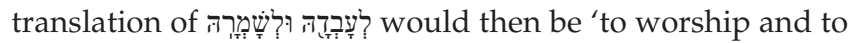
obey'. Man was called as a priest, not merely a worker and keeper of the garden and is characterised by 'worship and obedience' rather than just 'working' and 'keeping' (cf. Gaebelein 1990:45). ' $T$ The task of tilling the earth, as we are subsequently informed, was not imposed upon man till after his banishment from the Garden of Eden' (Gn 3:23; Cassuto 1961:122). The mandate to serve and guard covered the whole of human life. 'Creation includes the cultural and social endeavors of human existence and thus covers the whole of human life-personal, social, cultural' (Goheen \& Bartholomew 2008:39). ${ }^{3}$ Man's original vocation was to serve as priest over God's creation (Gn 1:28; 2:15) with the task of blessing all of creation and bringing it into an intimate relationship of worship with God. Man was 'put' into the garden 'in God's presence' where he could have fellowship with God (Gn 3:8), to work the garden, to take care of it and to bring out the beauty of God's creation as an expression of worship. The original task given to man (Gn 1:28; 2:15) involved more than cultivation; it included cultural preservation and development, it 'intended that the historical developments of creation should continue in the human cultivation of the rich potentials of God's creation through the responsible cultural activity of human beings' (Goheen \& Bartholomew 2008:41). ${ }^{4}$ The role of mankind as priests was to execute the task of caring for creation in a way that reflects our relationship with the Creator. The priestly task was to lead all of creation into God's 'rest' or 'safety', into the presence of the Lord (Ex 16:33-34; Lv 16:23-24; Nm 17:4; Dt 26:4, 10), which appears to be behind the author's use of 'put' in Genesis 2:15. The tasks of serving, guarding, worship and obedience are part of the priestly act of worship and consecrating creation to God as an expression of the imago Dei. 'The starting point of mission must be the

\footnotetext{
1.In Genesis 2:15 'domination is qualified and compared to service', argues Berthoud (2015:64).

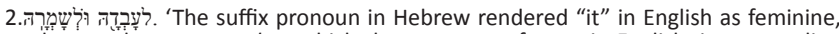
whereas the noun garden, which the pronoun refers to in English, is a masculine noun in Hebrew' (Gaebelein 1990:45) indicating that the task involved more than the cultivation of the earth.

3.'For example, Scripture teaches that marriage, a cultural and social development, has been created by God to be received with thanksgiving (1 Tm. 4:3-4); political authority is similarly described as ordained by God (1 Pt. 2:13)' (Goheen \& Bartholomew 2008:39-40).

4.'Neither God, nor animal, man is an intendant, a steward, an assistant-governor to the Lord' (Berthoud 2015:64), and penultimate a priest.
}

unequivocal recognition of the imago Dei in each and every human person' (Nothwehr 2010:115-116). ${ }^{5}$ Goheen and Bartholomew (2008:44) argue for the protection and caring for creation as participating in God's mission, but have eclipsed man's primary calling as priest. The role of mankind as priest over God's creation involves a dual mandate, cultural and redemptive, in God's re-direction of every aspect of creation to its healthy functioning intended goal. The cultural mandate involves ecological responsibility, economic activity, work, productivity, exchange and trade, politics, sports and competition, creativity and art, and all the aspects of culture. Mankind has a facilitating role in God's process of restoration after the Fall, which is described in terms of mission: Israel's mission in the Old Testament and the church's mission in Luke and Paul as part of God's unfolding redemptive and cultural mission. 'Although the whole earth is mine' (Ex 19:6), ${ }^{6}$ God commits to Israel the

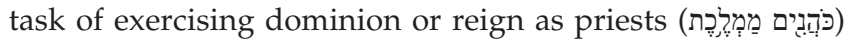
over his creation (Ex 19:4-6). The task of Israel as priests over God's creation is bound up with guarding or keeping the covenant (Ex 19:5). The church is a spiritual oĩkos [house] (1 Pt 2:5-9) for the purpose of being a 'holy priesthood', grounded in mankind's priestly role in Genesis $(1: 28 ; 2: 15)$. Israel was to be a nation of priests (Ex 19:4-6) and the church in the New Testament is a nation of priests (1 Pt 2:5-9) grounded in God's mission from Genesis (2:15) to the Gospels. It will climax with the full revelation and restoration of mankind as priests over God's creation and reign on earth ( $\operatorname{Rv} 1: 6 ; 5: 10 ; 20: 6)$. The stewardship committed to mankind (Gn 1:28; 2:15) is developed from the Old to the New Testament in which the term oikovoría could be translated as 'stewardship' (Lk 16:2, 4; Gl 4:2; Eph 3:2, 9; 1 Tm 1:4; Tt 1:7; 1 Pt 4:10), 'steward' (Lk 12:42; 16:1; 1 Cor 4:1; 9:17) and 'administration' (Eph 1:10).

\section{The relation of the stewardship motif in Old and New Testaments}

The task of stewardship in the Old Testament is expressed in the priestly calling of the nation of Israel to be holy (Ex 19:4-6; Dt 7:6; 14:21; 26:19; 28:9; Is 62:12) and by oikovo $\mu$ í $\alpha$, used twice in the LXX. These two occurrences are found in Isaiah 22:21 in which the message is that it is God who commits authority and oikovouí $\alpha$ to men (Is 22:21-22). The task of oikovouía involves a spiritual aspect and can be termed a spiritual or priestly stewardship or administration. ${ }^{7}$

The misconstrued concept of oikovorí $\alpha$ calls for a rediscovery of the biblical concept stewardship - the concept that God 5.Mission that does not engage in resistance to the evils in society is not the missio
Dei (cf. Bedford 2010:112). Bedford (2010:112) identifies the missio Dei as the
restoration of the imago Dei.

6.The missio Dei is the mission of God from creation to consummation. It is humanity with a mission (Gn 1:28; 2:15), Israel with a mission (Gn 3-11; 12; Ex 19:4-6), Jesus with a mission (Is 42:1; Ps 2:7-8) and the church with a mission (Is 43:10-12; 49:6; Ac 1:8; 13:47; cf. Wright 2008:64-66).

7.The Vulgate 15c. reads 'praepositus temple qui habitat in tabernacle', ['the one placed over the temple who dwells in the tabernacle'], and although Wildberger (1997:379, 386) explains it is a mistaken reading, 'the house of your master' (Is 22:18) is a reference to the Temple of the Lord. Wildberger (1997) neglects the fact that a sharp distinction between the secular and royal palace did not exist, and 'against' defines the nature of the mission of Isaiah 'to' the steward in 15b. 
has entrusted to all men a priestly stewardship based on the cultural and redemptive mandates (Gn 1:28; 2:15). The stewardship motif in the Old Testament provides the background or context for the use of oikovoría in New Testament and Luke. Stewardship is associated with the redemptive historical character of Luke-Acts in which oikovo $\mu$ í $\alpha$ is a concept in the overall nature of Luke. It is based on the 'responsible use of resources' or wise management of the resources at a person's disposal on the grounds of the 'creation' motif (cf. Reumann 1992:121). The identification of oikovoría merely with a creation motif in Luke, however, is to detach it from its redemptive historical character and causes disunities with its Christocentric core and the Trinity. The grounding of oikovoría on the creation or cultural mandate in isolation from the redemptive mandate places the focus on the human motivation and freedom to serve. It creates a dichotomy between the physical and spiritual in what essentially is a twofold aspect of the one task given in the original mandate to mankind (Gn 1:28; 2:15). All mankind possesses a responsibility on the bases of creation and the imago Dei [image of God] to take care of creation, but it is through the covenant of redemption that mankind serve as priests over creation. The imago Dei and the missio Dei are inseparably bound up together: the missio Dei will be fulfilled when the imago Dei is fully restored. The stewardship of creation, justice, wealth, and resources, grounded exclusively on the creation mandate motif in isolation from the redemptive motif, tends to self-interest, creaturely concerns, self-love and societal improvement. The imago Dei (Gn 1:26-27) is fully reflected in the dual nature of the task of stewardship grounded in the cultural and redemptive mandates. 'Humanity was given the task of exploring, discerning and developing the potential that God put in creation in loving communion with himself' (Goheen \& Bartholomew 2008:152). Mankind is involved in the priestly task through the proclamation of the gospel - a prophetic activity, which transforms society and is the basis for the restoration of creation. 'Paul reflected on his calling to mission, seeing it as the priestly task of making God known' (Wright 2008:124). 'Integrating creation stewardship into missions can help us rediscover the beauty of holistic ministry that does not separate the spiritual from the physical' (Sorley 2011:140). Mission that includes agricultural stewardship restores dignity and eliminates the spiritual and emotional poverty that afflicts many who see cultivating the earth and farming as something without meaning and dignity - holistic missions (cf. Sorley 2011:140). Holistic missions are a 'tangible witness to the fact that we are committed to Christ' (Sorley 2011:140). When Christ's love is demonstrated in practical ways such as striving to deal with diminishing natural resources and food supplies through missionaries with expertise in forestry, fisheries and sustainable agriculture, improved opportunities are cultivated for presenting the gospel and people are much more receptive and open to it (cf. Sorley 2011:139). Taking

8. It is through the gospel and redemption that a person becomes part of the fulfilment of God's purposes for creation (2 Cor 5:17). care of the earth and the proclamation of the gospel are part of the one purpose and plan of God.

\section{The purpose of Luke-Acts}

The purpose of Luke was not to explain precisely and give a detailed account, but to compile an orderly account that communicates a different nuance from Mark when the sequence of events as compared. Luke demonstrates that there is a oikovo $\mu$ í $\alpha$ [strategic order], which he points out. The prologues designation is an 'orderly account' (Ac 1:1) or a 'narrative designed to lead through' a carefully orchestrated plot, 'step by step' (cf. Ac 11:4; cf. Green 1995:36). There are no historical inaccuracies in Luke in terms of promising a chronological order of events, but when examined more closely it is not a chronological order of events. ${ }^{9}$ Luke's ordering of events is the identification of God's oikovoría of events with continuing the historical development of creation and human beings as responsible agents for cultural development. ${ }^{10}$ In Luke 4:38-39 and 5:10-11, in contrast to Mark 1:16-18, 30-31, the intention of the author is to point out that Jesus' healing of Simon Peter's mother-in-law was more than a periodic and loose association, which became more a closely knit fellowship through the calling of the first disciples. The word orderly in Luke 1:3 is not to be taken to mean chronological, as Jesus' healing of Simon Peter's mother-in-law (Lk 4:38-39) does not take place before the first calling of Simon Peter and the disciples in Luke. The first call of the disciples is placed after this event (Lk 5:1-11). In the account of Mark 1:29-31, Jesus entered the house with Simon, Andrew, James and John and the event is placed after the first call of the disciples (Mk 1:16-20). It is God's oikovorí $\alpha$ of events that is revealed in Luke. LukeActs should therefore not be read as a chronological order of history, but as the historical development to the climax of the revelation of all cultures' fullness (Ac 2:5-12; 15:14-18; 28:28; Rv 5:9-10; 21:26). Human beings are responsible for cultivating cultural activity in the historical development of creation (cf. Goheen \& Bartholomew 2008:41). According to Squires (1993), the purpose of Luke-Acts is to assure its readers that the events

were part of the plan of God and to provide them with the means of witnessing to the divine plan in such a way that it might be understood and appreciated in the Hellenistic world. (p. 194)

Luke-Acts was intended by Luke to be 'a missionary tool with the intention that they might use the story which he tells to further the Christian cause and make converts to Christianity' (Squires 1993:194). The two-key events, which are central to God's plan, are the passion of Jesus and the Gentile mission (cf. Squires 1993:186-187). The missio Dei is

\footnotetext{
9.The key turning point in the gospel is Luke $9: 51$ from which point Luke arranges his material according to the journey to the final destination of Jerusalem (LK 9:51, 53; 13:22, 31-35; 17:11; 18:31; 19:28, 41; cf. Huffman 2008:65). 'Luke sets little store $13: 22,31-35 ; 17: 11 ; 18: 31 ; 19: 28,41 ;$ cf. Huffman 2008:65). 'Luke sets little store
by exact indications of place and time, even where Mark in fact does so' (Du Plessis 1983:146; cf. Lk 8:22 with Mk 4:35).

10.Luke arranges his material according to the necessity of God's plan being fulfilled (Lk 4:42-44; 8:1; 16:16). 'It is improbable that Luke sets out to supply a chronological sequence - except in broad outline; his overriding intention is to indicate God's plan of salvation in the Christ-event' (Du Plessis 1983:147)
} 
the interpretive key to the events of Luke, and the Gentile mission is the key in Acts (cf. Squires 1993:189).

\section{Exploring the usage of oikovo $\mu i \alpha$ in Luke}

\section{The use of oikovouia in the context of the letter: The poor and missions}

Salvation in Luke includes the economic dimensions. The use of оiкоvонí in Luke's Gospel is to be read against the strong emphasis on the social dimension of salvation. Missions are the mission of Jesus Christ in the gospel who comes to fulfil the calling of the Servant in Isaiah (49:3; 53:11) to set the captives free from spiritual bondage and oppression. In Acts God gives tasks to the church and sends her into the world to be a witness (Ac 1:8) and to be a transforming presence in society. Mission is the mission of the church, which is to fulfil the ministry of the Servant in Isaiah (41:8). Mission in Luke-Acts connects the mission of Jesus with that of the church. 'The connection between Luke and Acts shows that the church's mission flows from the ministry of Jesus' (Goheen 2005:243). In Luke it is about the role of the gospel in redemption and its influence on social consciousness. For Luke oikovouía is the management of household, the preservation of culture and the care for creation, which indirectly makes the spread of the gospel possible. Luke does not directly connect oikovo $\mu$ í $\alpha$ with missions. It is connected through the role of oikovorí $\alpha$ in the

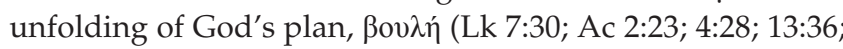
20:27). ${ }^{11}$ The significance of oikovoría in Luke for missions is that the proper management of resources will benefit the poor and oppressed. Post (2013) comments that:

This calling requires of the church to be concerned with the modern-day widows, orphans, and aliens - the single mother raising her family without a husband and the kids on the street who are essentially alone with uninvolved parents. (p. 120)

\section{Isaiah 61 and the empowering of the poor for active mission}

Mission in Luke-Acts is intrinsically linked to the Old Testament and mission in Isaiah. Bosch's missional reading of Luke (1991) begins in 4:16-30 with Jesus' ministry, which begins with him setting out the kingdom mandate of Isaiah 61:1-3. 'Jesus' contemporaries would have interpreted Isaiah 61:1-2 in terms of violent political liberation' (Goheen 2005:248). Jesus prophetic anointing (cf. Tuckett 1996:61-62) is revealed in his proclamation of the favourable year of the Lord, but he refuses to announce the day of vengeance. 'The kingdom mandate of Isaiah 61:1-3 shows how, in the space of three verses, the poor can be lifted from poverty to active mission' (Ring 2011:7). For Luke, social-responsibility and witness or mission go together. Jesus' announcement of what God is doing in salvation, are combined with challenges to join in what God is doing (cf. Wright 2005:53). According to Ring (2011), Isaiah 61 shows:

11.It is distinguished from $\theta \dot{\varepsilon} \lambda \omega$ ' to purpose, generally based upon a preference and desire' (Louw \& Nida 1988:30.58). how God's heart for the poor is not just to improve their circumstances, but to lift them into fully functioning members of the body of Christ and have them involved in effective mission. (p. 21)

Luke's Gospel does not simply 'patch up' the lives of the poor by lifting them out of poverty to a better lifestyle, but enables them to recognise the resources God has given them, the unique gifting and to be involved in effective mission to the community. It was written 'to enable people to recognize God's activity in the world, and then fall in step with it' (Wright 2005:58). The good news to the poor and disadvantaged people results in them becoming oaks of righteousness (Is 61:4-9), fully functioning members of society (cf. Ring 2011:22). It is about the priests of the Lord (Lk 4:18-19) who will fulfil a role amongst the nations (Ex 19:5-6; 1 Pt 2:9) in the bringing of the gospel (Is 61:1). In Isaiah 61 the prophecy is given that they:

shall be called the priests of the Lord; and they shall speak of you as the ministers of our God; and you shall eat the wealth of the nations, and in their glory you shall boast. (v. 6)

\section{Oikovoui $\alpha$ in Luke 12 and 16 and the poor}

Mission in Luke is about releasing, resourcing and equipping the poor and the rich, ${ }^{12}$ for world mission, the demonpossessed man is healed and sent on a mission to his native territory (Lk 8:39). Salvation for Luke is not limited to the relationship between God and his people, and the removal of sin. It includes the management of resources and people's gifting to make them agents of transformation in their communities. ${ }^{13}$ Luke, more than any other of the Gospels, refers to the oikoi resources that need to be managed (cf. Dyck 2013:14). ${ }^{14}$ Resources and personal gifts have been made available to all members of the household so that they are equipped to fulfil the calling and work of God. The vision communicated by Jesus in parable, miracle, and table fellowship is not merely of new persons, but of a new society. For Luke oikovo í $^{\alpha}$ is essentially about the task of management of resources and ${ }^{15}$ gifts in a relationship of accountability that the members of the household shared with one another as

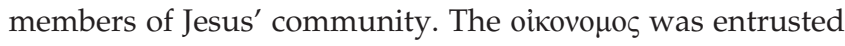
with the responsibility of the household's management to ensure that every person fulfilled his or her task in the household. It is the effective management of the household in its function in society that brought about transformation, which was essentially the task of the oikovoros. The role of the oikovoros in the missio Dei was to participate in the restoration of individuals, communities, nations, the environment, the world and the cosmos. The misuse of the resources by the

12.Bosch's argument is holistic and includes the responsibility of the poor and the rich.

13.Luke emphasises management, oikos, and money. The oikos or oikoin is the primary organization producing goods and services in the 1st century world (cf. Dyck 2013:14)

14.In particular, of a simple list of fixed oikos assets-possessions, property, and goods - Luke accounts for 17 of 25 (68 percent) mentions in all four Gospels combined' (Dyck 2013:14).

15.The parables have been read and personally appropriate and the communal character of the parables has been eclipsed. 
manager in Luke 16:1-15 prohibited the members of the household to fulfil their tasks and mission.

\section{The use of oikovouia in the eschatological framework of Luke}

The oikovoría passages (Lk 12:35-48 \& 16:1-13) such as the eschatological passages in Luke $(10: 42 ; 17: 20-37 ; 21: 8-9 ; 12-$ $19,24)$, are to be read in the context of Luke-Acts as a whole (cf. Marshall 2005:176). The story Luke develops, is one of mission (Marshall 2005:173) even though it is only in Luke 24:47-49 that there is a clear summons to missions. Luke-Acts concentrates on the task of the mission (Marshall 2005:175). The repeated point in the passages concerned with the end, is 'not yet' (Lk 21:8, 9, 12, 24) and these eschatological discourses provide a window of opportunity to witness and testimony (Marshall 2005:176). The concept of oikovouía in the Gospel of Luke is to be read against the story of Jesus' mission. In Acts the witness of Jesus is taken to the ends of the earth and it gives an account of how the gospel spread from Jerusalem to Rome (cf. Marshall 2005:171). In Acts 20:27 Paul, in his speech to the elders of the church of Ephesus, says that he preached the $\beta$ ov $\lambda$ i [plan or counsel] of God to them. It is the 'оiкоvонí $\alpha$ of the grace of God' (the gospel) given to Paul (Eph 3:2). The mission of Jesus and the disciples in the Gospel of Luke is developed and continued in the task of the church's mission in Acts and the Pauline epistles. The Holy Spirit enables the church to bear witness and testify to the gospel. The language and teaching of Acts is eschatological, and apocalyptic language of the gospel is absent from Acts (cf. Marshall 2005:174). It is the eschatological context that carries the mission of the church forward in Acts and the Pauline epistles. Eschatology, for Luke, functions to give hope and accountability (cf. Bock 2012:398). The expectation of the kingdom of Israel's restoration in Luke-Acts is an eschatological expectation (Lk 1:70; 21:1-38; Ac 1:6; 3:21). ${ }^{16}$ Jesus replaces the apocalyptic expectation of Israel with an eschatological expectation of the kingdom of God's restoration (Lk 20:27-40). ${ }^{17}$

\section{The use of oikovouia in the context of social responsibility}

The term oikovouía in Luke is used in a concrete sense in parables to indicate social responsibility and accountability as part of the task of stewardship given to mankind (Gn $1: 28 ; 2: 15)$. The Gospel of Luke is to be approached with a common stewardship given to all mankind, based upon the creation motif. The church is motivated by a second motif, namely redemption. The steward parable in Luke 16:1-13 is essentially about stewardship, redemption, restoration and transformation facilitated through a crisis. Redemption, restoration and the opportunity of transformation is presented in the crisis of the steward. The steward parables (Lk 12; 16) are misinterpreted when the socio-consciousness,

16.The attention of the disciples is directed away from the future and speculation about it to the need for missions, from apocalyptic expectation to eschatological prophecies that retain the fact of persecution.

17.The eschatological restoration of the kingdom is revealed in the exorcisms (cf. Lk 4:31-36; 8:26-39; 9:37-45; Ac 3:6; 16:18) and healing (Lk 5:12-16; 13:10-17 17:11-19; 18:35-42) and sending out his disciples (Lk 9:1-9; 10:1-23). which is inseparable from the gospel, is glossed over. The steward has the responsibility of giving to each person of the household their food allowance at 'the proper time' and 'the proper amount of food' (Lk 12:42). In doing so the steward releases, resources and equips the members of the household for mission. The oikovouo $\varsigma$ has two functions: a leadership and priestly function. Mankind's relation to God's creation was that he was to be priest over creation (Gn 1:28; 2:15), which has been restored through the gospel as the redeemed mankind serve as priests over God's creation (Is 61:6; $1 \mathrm{Pt}$ 2:5-9; Rv 1:6; 5:10; 20:6).

\section{The task of oikovouia of the restored mankind}

Luke uses a variety of terms, explicitly indicating stewardship

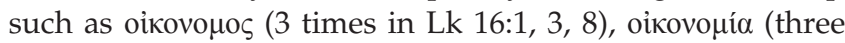
times in v. 2, 3, 4) and oikovo $\varepsilon^{\prime} \omega$ (v. 2). The frequency of Luke's use of related terms in Luke 12 shows that Luke has a particular interest in this motif (Kim 1998:160). Luke uses oikos for the household as the fundamental unit of social organization consisting of husband, wife, children, servants and slaves. Creed (1950:177) correctly claims that Luke

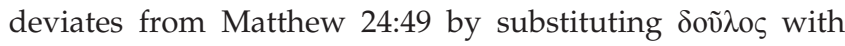

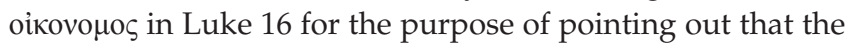
oikovo $\mu \mathrm{s}$ is not an ordinary slave, but a chief slave in the household. Thus, it can be thought of as a technical term (cf. Kim 1998:159). The activity of the oikovouos and the task of oikovoría have been translated in a variety of ways in the New Testament. For Paul the administration of the universe or cosmos by God is a oikovoría, a management and ordering of the cosmos (Eph 1:10), which, in Luke's thought and sense of the concept, it is in a narrower sense the management of the resources that have been entrusted by God for the wellbeing of creation. It is only in Luke 12:42 and 16:1-4 in the New Testament parables in which oikovouos is used in the sense of stewardship of possessions in a more secular sense (cf. Foster 1995:15). In these two parables oikovouía is the restoration of economical, religious, political, physical and social dimension of creation that is restored through oíкоvонía (cf. Foster 1995:15). 'Restoration does not mean a return to the undeveloped state of creation as it was in Eden' (Goheen \& Bartholomew 2008:134). The task of the oikovouos in Luke has a leadership and priestly dimension and has the connotation of caring for others. ${ }^{18}$ Caring for others is a form of worship to God and fulfilment of the priestly task (cf. Bovon 2013:237). The stewardship parables in Luke, when interpreted through David Bosch's proposed missional reading of Luke (1991:88, 104), calls God's people to be priests over creation, to bring spiritual healing, restoration, wholeness and transformation of individuals and society.

\section{$\lambda \varepsilon ı \tau 0 v \rho \gamma i ́ \alpha$}

The liturgical function of leading the household in worship

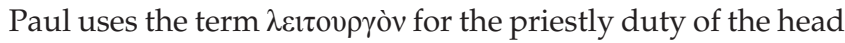
of the household and for proclaiming the gospel whereby the Gentiles are sanctified (cf. Rm 15:16). The sanctified mankind has been restored as a $\lambda \varepsilon \imath \tau o v \rho \gamma o ̀ s$, which extends beyond

18.'A slight medical connotation cannot be ruled out' (Bovon 2013:237) 
the liturgical responsibilities in the church to the household and through the household to all of creation for the task of the proclamation of the gospel. The head of the household,

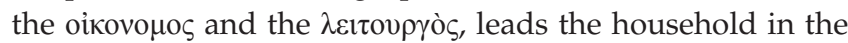
recognition and exercise of its priestly duties. ${ }^{19}$ The exercise of oikovo $\mu$ í $\alpha$ and $\lambda \varepsilon ı \tau o v \rho \gamma i \alpha$ are part of the restoration of God's new creational order, which is in the present and future (cf. Heb 9:10; Rv. 21:4), and an involvement in the liberation of creation from its decay (cf. Rm 8:21) through the reconciliation of all of God's creation to him (2 Cor 5:17-19; Col 1:20). The leadership task of $\lambda \varepsilon i \tau o v \rho y i \alpha$ is part of the restoration of the original purpose of God for the restoration of all of creation to its intended function of the worship of God.

\section{The parables and mission}

The lost and found parables in the Gospel of Luke have a missional function..$^{20}$ The parables of Luke 12-14 indicate a relation between the use of resources and salvation. Parables such as the parable of the rich fool (Lk 12:21), the great banquet (Lk 14:23) and the cost of being a disciple (Lk 14:33), which exhort the readers to use their resources for the poor have a missional function. The parables of Luke 15-16 indicate a relation between repentance and not using one's resources only for one's own benefit. The idea of stewardship is central in the parables in Luke 15-16 in the immediate context of the trilogy of lost and found parables, indicating God's mission to restore the lost (the lost sheep, the lost son) and what has been lost. The parables of the lost sheep and lost coin begin with a question as the steward parable does. The parables of the prodigal son and unjust steward are a pair and both begin with a character 'squandering' property that belongs to another. These parables associate redemption with finding what is lost and a realisation of the recklessness of waist in the steward parable indicates that redemption has an effect on the whole of life. In the parable of the shrewd steward (Lk 16:1-13) it is implied that there is a transformation in the thought and practice of the steward who begins to use the resources entrusted to him responsibly.

\section{Luke 16:1-13 and the crisis}

In the steward parable in Luke 16:1-13 the oikovous is appointed over the financial resources of the master to maximise his investments. The steward can be equated in the modern sense with an investment broker, 'much as a modern executive with a budget at his/her discretion' (Landry 2000:298). ${ }^{21}$ The steward has 'the confidence of the landowner, who charges him with the double task of overseeing the servants and the finances' (Bovon 2013:237). He is accused by his master of misappropriation of funds or spending funds on personal items. The crisis in the parable is evident in the question, 'What shall I do, since my master is taking away the stewardship from me?' (Lk 16:3). It indicates

19.The relation between Luke and Paul is in terms of the function of leading the household. Luke uses oikovouí $\alpha$ and Paul $\lambda \varepsilon i \tau o v \rho \gamma i \alpha$ for the leadership task.

20.The lost sheep, lost coin and prodigal or son (Lk 15) are about God finding the lost person.

21.The master can reasonably surmise that the steward has been using his employer's funds for selfish and immoral purposes (cf. Landry 2000:298). that the crisis is that, in his role as oikovo $\mu$ os, the steward is in a position of being demoted from his responsibility to the status of common drudge (cf. Beavis 1992:49). The crises of the steward's situation in Luke 16:3 and Jesus' exhortation to use worldly wealth to gain friends (Lk 16:8-9), has a missional application, because wealth is to be used to secure a social network that facilitates the spread of the kingdom. It is literally a 'visitation of his Lord' (Johnson 1991:247). The task of the oikovouo $\varsigma$ was to take care of the household and the administrational and missional element was that he was to distribute resources to meet the needs of the household servants acting on behalf of the master. The distribution of resources to meet the needs is essential to missions. Beavis (1992:49) suggests that the verb бкó $\pi \tau \varepsilon ı$ (Lk 16:3) means that, as a slave, he is in danger of being sent off to hard labour in the quarries, a form of imprisonment - the worst fate imaginable for a slave. The steward is not to be directly equated with a slave, ${ }^{22}$ but a manager who has fears, which are in connection with returning to subsistence farming or agricultural and gardening livelihood - 'to till the ground, to dig' (Louw \& Nida 1996:43.3). This is what the steward is apprehensive about. ${ }^{23}$ It is the fear of manual labour, the loss of status, position, privilege or transformation of motives that motivated the manager. The crisis provides an opportunity for every party to experience the redemption of God. The response of the manager to the crises resulted in him being 'praised for having the qualities of a manager' (Johnson 1991:245). Even though the steward squandered the master's property, the situation of crisis becomes an opportunity for redemption and restoration for his master's honour to be restored and his reputation as a good steward to be salvaged. Landry (2000) comments:

Luke 16:8-9 clearly shows Jesus urging his listeners to follow the example of the prudent steward, who has taken 'dishonest wealth' or 'ill-gotten gains' and used it shrewdly - restoring his reputation, earning his master a reputation for nobility and generosity, and relief to his master's debtors. (p. 308)

The parable is essentially about the possibility of redemption, restoration and transformation, facilitated through a crisis event. Redemption, restoration and the opportunity for transformation present in the crisis are elements of missions.

\section{Stewardship of the household by the Jewish religious institution}

The parable of Jesus in Luke 16 is a comment directed at the Pharisees as a religious institution. Jesus makes the statement, 'I tell you, use worldly wealth to gain friends for yourselves, so that when it is gone, you will be welcomed into eternal dwellings' (Lk 16:9). The use of wealth is related to eternal dwellings. The central verses are Luke 16:4 and 9. In 'v. 9b Jesus gives the purpose of or the reason for his exhortation in v. 9a' (Ireland 1992:99). A parallel exists between this clause and Luke 16:4b. 'In doing so Jesus sets up the analogy between the steward and the disciples' (Ireland

\footnotetext{
22.The oikovouos was not a slave (Bovon 2013:237) as suggested by Beavis.

23. Beavis bases her entire interpretation and claim that the steward is a slave, but for the interpretation to follow, it is not a decisive factor (cf. Landry 2000:296).
} 
1992:100). The contrast is between the Pharisees who were dishonest managers of God's household. The Pharisees used their position for their own benefit and the disciples, who were to be wise and faithful stewards. The Pharisees in the discharge of oikovouía, entrusted to them by God, misused their authority and power as the steward has. There is an irony in the parable: the steward realises the threat of loss, but the Pharisees are oblivious thereof. We find in the writings of Luke 'pointers for Christians on how to come to terms with worldly power and not remain, sociologically, a sect of outsiders' (Reumann 1992:89). For Luke oikovoría is directed towards the well-being of the community or society and at the role assigned to human beings as stewards of God's resources. The use of oikovoría in the parable of Jesus is addressed to the corrupt religious structures, which were to be structures of transformation and renewal in society, but were identical to that of the world. In Luke 16:9 the steward's debt-reduction is interpreted positively: the steward realised his predicament and reduced people's debts to earn the favour of his master. The disciples and Pharisees are challenged to use their resources and relationships for the benefit of their master and to focus on the eternal habitation. The nuanced

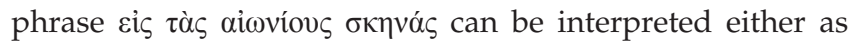
'reception into heavenly dwellings' or 'reception into the consummated kingdom of God' (Ireland 1992:104). The interpretation of the consummated kingdom of God accords with God's kingdom and his wisdom in Luke as no hidden secrets (cf. Cheong 2001:54). A contrast is made between worldly stewardship in Luke 16:4 and the stewardship the disciples and readers have to exercise. The goal of biblical stewardship is to use wealth and possessions not merely for this world, but with the goal of securing entrance into future heavenly dwellings and kingdom. The missional application suggests how the audience and the reader can find favour with God. It is to use resources to 'win' people and serve their master.

\section{The stewardship parable in Luke 12:35-48}

\section{The wisdom and faithfulness of the steward in Luke}

A distinction exists between Luke and Paul's concept of oikovoría. In Luke the sense of oikovoría is used in the redemption and transfiguration of the present world and not in the sense of substituting another world for this one. In Luke the relation is between God's creation and redemption, whereas in Paul the sense of oikovoría is found in the relation between redemption and God's creation and the heavenly realm (Eph 1:3, 10; 1:20; 2:6; 3:10; 6:12). The Lucan concept of оiкоvонí $\alpha$ has the sense of the 'responsible use of resources', 'the challenge is shocking, but simple and direct' (Cheong 2001:57). In Luke's sense the kingdom of God is revealed instead of concealing it as in Matthew specifically in the stewardship parables through the wise management of resources at one's disposal. The Lucan parables are missional as 'the Lucan kingdom is graciously and generously offered to those who are lost'24 (Cheong 2001:53). The parable has a missional orientation, because it is about a fundamental evaluation of possessions in light of the kingdom, which will lead the wise disciple to use his possessions in the service of the needy.

\section{Luke 12:40-48 and management of the socio-economic resources of the household}

The management of the household was presided over by

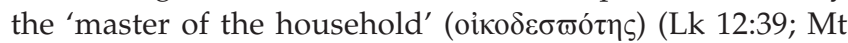
$13: 27,52 ; 20: 1 ; 21: 33)$. The oikovouos was appointed over the household to manage the financial resources of it. The task of the oikovouos is understood on a Lucan level as directed at the day-to-day administration of the household matters. The meaning of oikovoría in Luke is set against the background of the social-economic management of the household or the oikos. The oikos had a hierarchical quality to it, connecting administration and management. The

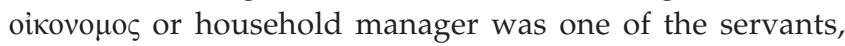
slaves or freedman appointed as a steward to manage

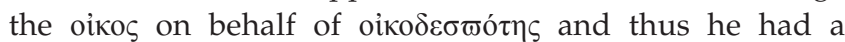
vested interest. The faithful slave is rewarded with more responsibility (Lk 12:44; 19:17, 19; Mt 24:47; 25:21, 23). The term oikоvо $\mu$ o $\zeta$ is used for the person assigned with the task of the management of God's household on behalf of him, but

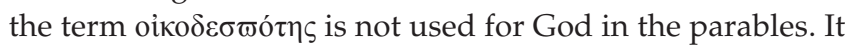
is God who places a steward in charge of the household, who has been 'put in charge of his servants to give them their food allowance at the proper time' (Lk 12:42, NIV). It is

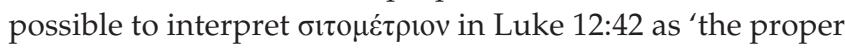
amount of food'. The task of the steward was to distribute the daily food rations in expectation of his master's return and so he will be entrusted with a greater responsibility to manage all the master's property (Lk 12:42-44; cf. 16:10-12; cf. Carrol 2012:274). The steward who has demonstrated faithfulness in the earthly tasks 'now' assigned to him and has fulfilled these tasks faithfully will be given the greater responsibility of management in the 'not yet' kingdom of Jesus Christ. The steward was expected to demonstrate understanding resulting from insight and wisdom (cf. Mt $7: 24)$, and the faithful discharge of his responsibilities. In Greco-Roman culture the oikovoros was given considerable responsibility and 'authority to command others' (Mt 24:45) 'that extended to instructing the wife on how to run the household and was more than 'good housekeeping' (Reumann 1992:12).

\section{The context of the imminent return of the Christ in Luke 12:35-39}

In Luke 12:39 the exercise of stewardship is in the context of the imminent return of the 'master of the household', the Lord. The stewards, who have been appointed, are exhorted to be watchful, not to fall asleep and allow the house of their master to be broken into and his possessions stolen. Stewardship in Luke 12:39 is broader than the management of resources; it includes wealth and poverty, but it is essentially about the spiritual well-being of God's children entrusted to the steward. It is the divine mercy of God, which is demonstrated and made known through the management entrusted to the steward. The stewardship parable is a critique on the Jewish leadership in Jesus' days who were 
bad stewards over God's children and allowed the masters house to be broken into. The context is missional, because it addresses the members of the household who are to 'be ready for service' and to 'have your lamps lit or burning' and is connected to the parousia (Lk 12:35). The exhortation in Luke exhorts each member of the household to a social and missional responsibility. They are to use their possessions for the extension of God's kingdom. There is nothing to suggest that the early Christian spent their time passively waiting for the parousia (cf. Marshall 2005:176). Luke is misinterpreted when the socio-consciousness, which is inseparable from the gospel, is glossed over. The parable is not simply about the grace of God, but how the household deals with resources it has as evidence of having received the grace of God. The gospel of grace evokes a social-consciousness that is an essential element of missional involvement.

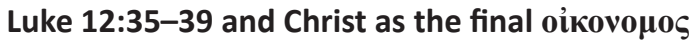

In Luke 12:35-39 it is God who is master of the household and the oikovouo $\zeta$ is 'the faithful and wise steward, whom the master will set over his household' (Lk 12:42). The faithful servants are 'truly blessed' as the Lord will 'dress himself to serve, will have them recline at his table and will come and wait on them' (Lk 12:37). The oikovouos is an illusion to the faithful Jewish servants and finally Christ, 'the Lord over the servants, whom his master will set over his household, to give them their portion food at the proper time?' Christ is the final oíкоvоно whom God will set over his household, and in this sense there is a development of the oikos idea from Luke to Paul: Luke is concerned with the practical management of the oikos and Paul the metaphorical concept (Eph 2:21-22). Following La Verdiere and Thompson (1976:582), Bosch (1991:85) believes that Luke wrote his gospel in the 80's during the reign of the Roman emperor Domitian to Gentile communities in transition. 'Much water had passed under the bridge since the time of Jesus even since the time of the missionary journeys of Paul' (Goheen 2005:240-241). If this is so then Luke may have been influenced by Paul and not vice versa. In terms of a salvation historical line, 'according to Bosch, Luke is concerned primarily with ecclesial formation that is rooted in, consisted with, and an extension of Jesus' mission' (Goheen 2005:241). Luke's understanding of missions was most certainly influenced by Paul; yet, Paul's concept of mission is not the same as Luke's. Paul sets out the mission of the church and Luke the church-in-mission indicating a development from Paul to Luke in terms of practical application.

\section{Missional application}

There is a diversity of understandings of mission amongst the first witness of the New Testament: 'the New Testament does not reflect a uniform view of mission, but rather, a variety of 'theologies of mission' (Bosch 1991:16; Goheen 2005:237). Luke writes two books in order to show the line of redemption and mission from Jesus, Paul and the church in Acts. 'Luke unites the time of Jesus and the time of the church in one era of the Spirit' (Bosch 1991:87; Goheen 2005:242). However, the dispensation of the Spirit in the Gospel of Luke is not to be identified directly with the dispensation of the Spirit in Acts. The gospel spread through the institution of the household. In the Early Church Christian missionaries made a deliberate point of gaining whatever households they could as lighthouses, so to speak, from which the gospel could illuminate the surrounding darkness (cf. Green 2004:270). It was through the Christian household that Christianity began to make an impression on surrounding paganism (cf. Green 2004:260). 'In Luke-Acts the household emerges as the prominent sphere and symbol of the reception of the gospel, Christian identity and solidarity in the Spirit' (Neyerey 1991:230). A missional reading of Luke-Acts and Paul renders God's mission through God's people in their engagement with God's world (cf. Wright 2010:103).

\section{Conclusion}

The term oikovopía in Luke 12 and 16 is used in a concrete for the task of management of the resources God has given. The Gospel of Luke is to be approached with a common stewardship given to all mankind based upon the motif of creation. The church is motivated by a second motif: redemption. Luke uses oikovoría in the context of the growth of social consciousness and social responsibility of the household as foundational to the proclamation of the gospel. The role of the oikovoros is both a leadership and priestly function. Mankind's relation to God's creation was that he was to be priest over creation (Gn 1:28; 2:15) and through the gospel they have been restored as priests over God's creation (Is 61:6; 1 Pt 2:5-9; Rv 1:6; 5:10; 20:6). The steward parable in Luke 12:35-39 is misinterpreted when the socioconsciousness, which is inseparable from the gospel, is glossed over. The steward has the responsibility of giving to each person of the household their food allowance at 'the proper time' and 'the proper amount of food' (Lk 12:42). In doing so the steward releases, resources and equips the members of the household for mission. The steward parable in Luke 16:1-13 is essentially about the possibility of redemption, restoration and transformation facilitated through a crisis. Redemption, restoration and the opportunity for transformation present in the crisis are elements of missions.

\section{Acknowledgements Competing interests}

The author declares that he has no financial or personal relationships which may have inappropriately influenced him in writing this article.

\section{References}

Beavis, M.A., 1992, 'Ancient Slavery as an interpretative context for the New Testament Servant parables with special reference to the Unjust Steward (Lk 16:1-8)', Journal of Biblical Literature 111(1), 37-54. http://dx.doi.org/10.2307/3267508

Bedford, N., 2010, 'Do not fear go: The commission of theological feminism in the mission of the Church', in O.U. Kalu, P. Vetanayagamony, \& E. Kee-Fook Chia (eds.), Mission after Christendom: Emergent themes in contemporary mission, pp. 100Mission after Christendom: Emergent them
127, Westminster John Knox, Louisville.

Berthoud, P.E., 2015, 'The covenant of creation, the cultural mandate and missions', in P.A. Lillback \& H.G. Stoker (eds.), A reformed covenant perspective: Understanding Christian mission in a changing world, A covenantal vision for global missions in the reformed tradition conference, North-West University, Potchefstroom, July 30-31, 2015, pp. 53-74. 
Bosch, D., 1991, Transforming mission: Paradigm shifts in theology of mission, Orbis Books, Maryknoll.

Bovon, F., 2013, Luke 2: A commentary on the Gospel of Luke 9:51-19:27: Hermeneia: A critical and historical commentary on the Bible, Fortress Press, Minneapolis.

Carrol, J.T., 2012, Luke: A commentary. The New Testament library, John Knox Press, Louisville.

Cassuto, U., 1961, A commentary on the book of Genesis: Part one from Adam to Noah, Magness Press, Hebrew University, Jerusalem.

Cheong, C.-S.A., 2001, A dialogic reading of the steward parable (Lk 16:1-9), Peter Lang, New York. (Studies in Biblical Literature, vol. 28).

Creed, J.M., 1950, The Gospel according to St Luke, Macmillan, London.

Du Plessis, I.J., 1983, 'The Gospel according to Luke: Introduction and theology', in A.B. du Toit (ed.), Guide to the New Testament IV: The synoptic Gospels and Acts: Introduction and theology, pp. 144-164, Orion Publishers, Midrand.

Dyck, B., 2013, Management and the Gospel: Luke's radical message for the twenty first century. Palgrave Macmillan Publishers, London.

Foster, R.A., 1995, 'Stewardship: Sign and substance of the Christian life as taught in the New Testament', South Western Journal of Theology 37(2), 15-22, Spring.

Gaebelein, F.E., 1990, The expositors Bible commentary, vol. 2, Zondervan, Grand Rapids.

Goheen, M., 2005, 'A critical examination of David Bosch's missional reading of Luke', in G. Bartholomew, J.B. Green, \& A.C. Thiselton (eds.), Reading Luke: Interpretation, reflection, formation, pp. 229-264, Zondervan, Grand Rapids.

Goheen, M. \& Bartholomew, C., 2008, Living at the crossroads: An introduction to Christian worldview, SPCK, London.

Green, J.B., 1995, Theology of Luke, Cambridge University Press, Cambridge.

Green, M., 2004, Evangelism in the Early Church, Eerdmans, Grand Rapids.

Huffman, D.S., 2008, 'What did Luke really care about?' in K. Berding \& M. Williams (eds.), What the New Testament authors really cared about: A survey of their writings, pp. 59-74, Kregal Academic Press, Grand Rapids.

Ireland, D.J., 1992, Stewardship and the kingdom of God: An historical, exegetical, \& contextual study of the parable of the Unjust Steward in Luke 16:1-13, E.J. Brill, Leiden.

Johnson, L.T., 1991, The Gospel of Luke: Sacra Pagina, Liturgical Press, Collegeville.

Kim, K.-J., 1998, Stewardship and Almsgiving in Luke's theology, Sheffield Academic Press, Sheffield. (JSNT-supplement series 155).

Landry, D., 2000, 'Honour restored: New light on the parable of the prudent steward (Luke 16:1-8a)', JBL 119(2), 287-309.
La Verdiere, E.A. \& Thompson, W.G., 1976, 'New Testament communities in transition: A study of Matthew and Luke', Theological Studies 37, 593-597.

Louw, J.P. \& Nida, E.A., 1988, Greek-English lexicon of the New Testament: based on semantic domains, United Bible Societies, New York.

Louw, J.P. \& Nida, E.A., 1996, Greek-English lexicon of the New Testament: Based on semantic domains, United Bible Societies, New York.

Marshall, I.H., 2005, 'Political and eschatological language in Luke', in G. Bartholomew, J.B. Green, \& A.C. Thiselton (eds.), Reading Luke: Interpretation, reflection, formation, pp. 157-177, Zondervan, Grand Rapids.

Neyerey, J.H., 1991, The social world of Luke-Acts: Models for interpretation, Hendrickson Publishers, Peabody.

Nothwehr, D.M., 2010, 'Defining "Racisms": Understanding our globalized, terrorized, ecologically threatened world', in O.U. Kalu, P. Vetanayagamony, \& E. Kee-Fook Chia (eds.), Mission after Christendom: Emergent themes in contemporary mission, pp. 115-127, Westminster John Knox Press, Louisville, KY.

Post, S.M., 2013, 'A missional approach to the health of the city', in S.T. Logan (ed.) Reformed means missional: Following Jesus into the world, pp. 110-129, New Growth Press, Greensboro.

Reumann, J., 1992, Stewardship and the economy of God, Eerdmans Publishing, Grand Rapids.

Ring, N., 2011, The poor deserve the best: A manual for good practice, Newfrontiers, Claredon Villas.

Sorley, C., 2011, 'Christ, creation, stewardship, and missions: How discipleship into a Biblical worldview on environmental stewardship can transform people and their land', International Bulletin of Mission 35(3), 137-143 July.

Squires, J.T., 1993, The plan of God, Cambridge University Press, Cambridge. (Society of the New Testament Studies, 76).

Tuckett, C. 1996, Luke, NTG, Sheffield Academic Press, Sheffield.

Van Aarde, T.A., 2015, 'The use of oikovouía for the missional plan and purpose of God in Ephesians 1:3-14', Missionalia 43(1), 45-62, April. http://dx.doi.org/10.7832/43-1-43

Wildberger, H., 1997, Isaiah 13-27: A continental commentary, transl. T.H. Trapp, Fortress Press, Minneapolis.

Wright, C.J.H., 2008, Mission of God: Unlocking the Bibles grand narrative, InterVarsity Press Academic, Downers Grove.

Wright, C.J.H., 2010, The mission of God's people: A Biblical theology of the Church's mission, Zondervan, Grand Rapids.

Wright, S.I., 2005, 'Luke', in K.J. Vanhoozer (ed.), Theological interpretation of the New Testament: A book by book survey, pp. 50-59, Baker Academic, SPCK, Grand Rapids, London. 